\title{
The effect of high-sugar grass on predicted nitrogen excretion and milk yield simulated using a dynamic model
}

\author{
J. L. Ellis, ${ }^{\dagger} \dagger^{1}$ J. Dijkstra,† A. Bannink,‡ A. J. Parsons,§ S. Rasmussen,§ G. R. Edwards,\# E. Kebreab,॥ \\ and J. France* \\ ${ }^{*}$ Centre for Nutrition Modelling, Department of Animal and Poultry Science, University of Guelph, Guelph, ON, Canada N1G 2W1 \\ †Animal Nutrition Group, Wageningen University, 6700 HB Wageningen, the Netherlands \\ $\ddagger$ Wageningen UR Livestock Research, 8200 AB Lelystad, the Netherlands \\ $\S A g R e s e a r c h$, Palmerston North 4442, New Zealand \\ \#Faculty of Agriculture and Life Sciences, Lincoln University, Lincoln 7647, New Zealand \\ IIDepartment of Animal Science, University of California, Davis 95616
}

\section{ABSTRACT}

High-sugar grass varieties have received considerable attention for their potential to reduce nitrogen $(\mathrm{N})$ excretion and increase milk yield in cattle. However, considerable variation exists in the magnitude of response in published results. The purpose of this study is to explain the variation in response using a dynamic mechanistic model to predict observed $\mathrm{N}$ and milk yield results from the literature, and from simulated data. Examined effects were (1) water-soluble carbohydrate [WSC; g/kg of dry matter (DM)] increase; (2) change in crude protein (CP) and neutral detergent fiber (NDF) content of the plant with WSC increase; and (3) the level of $\mathrm{N}$ fertilization. The database for evaluation of model $\mathrm{N}$ and milk yield predictions consisted of 4 published studies with 28 treatment means for which high-sugar grasses were being evaluated. Water-soluble carbohydrate content of the diets ranged from 95 to 248 $\mathrm{g} / \mathrm{kg}$ of DM, CP content ranged from 115 to $263 \mathrm{~g} / \mathrm{kg}$ of DM, and the NDF content ranged from 400 to 568 $\mathrm{g} / \mathrm{kg}$ of DM. Urine $\mathrm{N}$, milk $\mathrm{N}$, and total $\mathrm{N}$ excretion were predicted well by the model and followed the directional pattern of observed values within each study. Simulation results showed that the $\mathrm{N}$ utilization ratio increased as the WSC content of the diet increased, but to varying degrees depending on the grass scenario examined. The greatest benefit in terms of $\mathrm{N}$ utilization ratio and urine $\mathrm{N}$ levels were seen when the WSC content of grass increased at the expense of $\mathrm{CP}$, followed by a 50:50 CP and NDF mix, followed by a trade for NDF. Simulated milk yield decreased slightly when WSC increased at the expense of $\mathrm{CP}$, increased slightly when it increased at the expense of a $\mathrm{CP}$ and NDF

Received December 3, 2010.

Accepted February 8, 2011.

${ }^{1}$ Corresponding author: jellis@uoguelph.ca mix, and increased most when WSC increased at the expense of NDF. Results were amplified slightly under conditions of low- $\mathrm{N}$ fertilization and in the absence of grain feeding. Overall, modeling is useful as an explanatory tool. The variation from results in the literature with high-WSC grass feeding may be, at least in part, the result of the level of WSC ( $/ \mathrm{kg}$ of DM) increase, concurrent changes occurring within the $\mathrm{CP}$ and $\mathrm{NDF}$ fractions of the plant, and the plane of nutrition of the diet (grain feeding and $\mathrm{N}$ fertilization levels).

Key words: high-sugar grass, nitrogen, milk yield, modeling

\section{INTRODUCTION}

Feeding high-sugar grass varieties to pastured cattle is proposed as a means to reduce $\mathrm{N}$ excretion in urine and feces, lessen the environmental impact of pastured cattle, and potentially increase milk yield. The total amount of $\mathrm{N}$ excreted by cattle can be significantly reduced by reducing the dietary $\mathrm{CP}$ content (Castillo et al., 2000; Kebreab et al., 2002), but N excretion is not exclusively determined in this way. The proposed mechanism of the high-sugar grass mitigation strategy is that for a high-producing animal on pasture, rumen microbes lack adequate supply of energy (carbon) for microbial growth relative to the large amount of available protein $\mathrm{N}$ in the diet. This nutrient asynchrony results in large amounts of $\mathrm{N}$ being lost from the rumen as ammonia instead of being incorporated into microbial protein, most of which is subsequently excreted as urea in the urine. It has been proposed that increasing the sugar content of grasses could rectify the imbalance of carbon and $\mathrm{N}$ being delivered to the rumen microbes, thereby making $\mathrm{N}$ utilization by the microbes more efficient, decreasing $\mathrm{N}$ loss from the animal and increasing the supply of $\mathrm{CP}$ to the ruminant (Miller et al., 2001a,b).

Edwards et al. (2007) produced a comprehensive review of the trials conducted to date by the 3 main groups 
that have been participating in sugar grass research: the UK studies (Miller et al., 2000, 2001a,b; Moorby et al., 2006), the Dutch studies (Tas et al., 2005, 2006a,b; Taweel et al., 2005a,b, 2006), and the New Zealand studies (Tavendale et al., 2006; Cosgrove et al., 2007). Edwards et al. (2007) concluded that the lack of response in terms of $\mathrm{N}$ excretion to high-sugar grasses in some trials could be that despite large differences in the water-soluble carbohydrate (WSC) content of tested forages, only small differences in the ratio of the WSC content:CP content in dietary dry matter (WSC:CP) actually existed. Compiling and graphing the results showed that only high WSC:CP ratios $(>0.7)$ led to a decrease in the proportion of $\mathrm{N}$ intake excreted from the animal. However, this reduction could be achieved by an increase in the WSC content or by a decrease in the $\mathrm{CP}$ content of the diet. These 2 scenarios may have very different effects on digestibility and milk yield. Other claims of the potential benefits of feeding high-WSC grasses include increasing grass palatability, DMI, and milk production (Miller et al., 2001a; Lee et al., 2002; Abrahamse et al., 2009).

The purpose of this study was, therefore, to attempt an explanation for the variation in $\mathrm{N}$ excretion and milk yield responses to high-WSC grasses reported in the literature by (1) using a dynamic mechanistic model to evaluate the capacity of the model to reproduce observed variation in $\mathrm{N}$ excretion and milk yield results; and (2) performing a model behavioral analysis, keeping DMI constant, and evaluating a wide variety of high-WSC grass compositions and feeding scenarios. With respect to the latter, the WSC fraction of grass (g/ $\mathrm{kg}$ of DM) was increased by 3 levels: 20, 60, and 90 $\mathrm{g} / \mathrm{kg}$ of DM at the expense of CP, NDF, or a 50:50 split of CP and NDF; high and low N levels of the grass were simulated representing high and normal $\mathrm{N}$ fertilization levels; and simulations were performed with and without grain as a supplement to the diet.

\section{MATERIALS AND METHODS}

\section{The Model}

A modified version of the rumen model of Dijkstra et al. (1992) was used to simulate effects of high-WSC grasses on $\mathrm{N}$ excretion and milk yield. The model simulates the digestion, absorption, and outflow of nutrients in the rumen and hindgut, and represents $\mathrm{N}$, carbohydrate, lipid, microbial, and VFA transactions. Modifications to the original model of Dijkstra et al. (1992) include an updated $\mathrm{pH}$-dependent VFA stoichiometry of Bannink et al. (2008) instead of the original stoichiometry of Murphy et al. (1982), a hydrogen balance sub-model and hindgut fermentation model developed by Mills et al. (2001), and calculations for $\mathrm{N}$ excretion developed by Reijs (2007). The empirical equations of Seo et al. (2006) were used for the fractional passage rate in the rumen. The original model, as well as the modifications and additions made to the model in the subsequent publications, has been tested on independent data in those publications. The original Dijkstra model, plus the subsequent series of additions and Reijs excretion equations, will be referred to as the "modified Dijkstra model" in this publication.

Nitrogen Excretion. The equations on N excretion developed by Reijs (2007) were included in the model so that the outputs from the digestion part of the model become the inputs required for the Reijs excretion equations. A schematic representation of the $\mathrm{N}$ excretion part of the model is shown in Figure 1. The Dijkstra model is used to predict outflow of undigested feed and microbial material from the rumen and intestine. Sources of fecal N include (1) endogenous N, (2) microbial $\mathrm{N}$, and (3) potentially degradable and undegradable feed protein, with assumptions on $\mathrm{N}$ content in each component.

Urinary $\mathrm{N}(\mathrm{g} / \mathrm{d})$ was calculated according to

$$
\mathrm{N}_{\text {urine }}=\mathrm{N}_{\text {feed }}-\mathrm{N}_{\text {milk }}-\mathrm{N}_{\text {feces }}-\mathrm{N}_{\text {retention, }}
$$

where $\mathrm{N}_{\text {retention }}(\mathrm{g} / \mathrm{d})$ is calculated assuming $22.1 \mathrm{~g}$ of $\mathrm{N}$ for every $1 \mathrm{~kg}$ of BW change per day for dairy cattle (AFRC, 1993). Urea $\mathrm{N}$ is calculated as the difference between $\mathrm{N}_{\text {urine }}$ and the sum of $\mathrm{N}$ in other urinary constituents. The non-urea-like urinary $\mathrm{N}$ components were calculated based on values found in the literature and are given in Reijs (2007). From these equations, total $\mathrm{N}$ excretion can be estimated, as well as dividing it into its components.

Milk Yield. Nutrients absorbed from the gastrointestinal tract can be classified as glucogenic, lipogenic, or aminogenic nutrients. The amount of ME available for absorption is calculated from these nutrients and their respective energy contents. Calculated milk yield is determined by the most limiting supply among glucogenic nutrients, aminogenic nutrients, lipogenic nutrients, and ME (Dijkstra et al., 1996). If the supply of glucogenic nutrients is first limiting, aminogenic nutrients in excess may be used for gluconeogenesis, assuming $0.6 \mathrm{~g} / \mathrm{g}$ of the absorbed AA to be glucogenic (Dijkstra et al., 2008).

Fat- and protein-corrected milk yield (3.5\% fat and $3.2 \%$ protein; $\mathrm{kg} / \mathrm{d})$ was calculated as $0.3246 \times$ milk yield $(\mathrm{kg} / \mathrm{d})+12.86 \times$ milk fat $(\mathrm{kg} / \mathrm{d})+7.04 \times$ milk protein $(\mathrm{kg} / \mathrm{d})$ (Bernard, 1997). 


\begin{tabular}{|c|c|c|c|}
\hline & & \multicolumn{2}{|c|}{ EXCRETION } \\
\hline \multirow{5}{*}{$\begin{array}{l}\text { Model of } \\
\text { rumen and } \\
\text { hind gut } \\
\text { fermentation } \\
\text { and intestinal } \\
\text { digestion, } \\
\text { nutrient } \\
\text { absorption } \\
\text { and milk } \\
\text { production }\end{array}$} & \multirow{2}{*}{$\begin{array}{l}\text { Intermediary } \\
\text { metabolism }\end{array}$} & $\begin{array}{l}\text { Non-urea-like } \\
\text { components: } \\
\text { Crn, Cr, Hi, Xa, Aa }\end{array}$ & \multirow{2}{*}{$\begin{array}{c}\mathbf{U} \\
\mathbf{R} \\
\mathbf{I} \\
\mathbf{N} \\
\mathbf{E}\end{array}$} \\
\hline & & $\begin{array}{l}\text { Urea-like } \\
\text { components: } \\
\text { Ue, Ua, Al }\end{array}$ & \\
\hline & $\begin{array}{l}\text { Intestinal secretion, } \\
\text { endogenous proteins }\end{array}$ & $\begin{array}{l}\text { Fecal endogenous } \\
\text { biomass }\end{array}$ & \\
\hline & $\begin{array}{l}\text { Microbes from the } \\
\text { rumen \& large } \\
\text { intestine }\end{array}$ & $\begin{array}{l}\text { Fecal microbial } \\
\text { biomass }\end{array}$ & $\begin{array}{l}\mathbf{E} \\
\mathbf{C} \\
\mathbf{E}\end{array}$ \\
\hline & $\begin{array}{l}\text { Rumen-degradable } \\
\text { protein \& rumen } \\
\text { undegradable protein }\end{array}$ & Protein & \\
\hline
\end{tabular}

Figure 1. Schematic representation of the modified model used for this evaluation. Nitrogen excretion equations are from Reijs (2007), and nutrient absorption from the rumen, small and large intestine, as well as intermediary metabolism outflows are predicted from the Dijkstra model. $\mathrm{Crn}=$ creatinine, $\mathrm{Cr}=$ creatine, $\mathrm{Hi}=$ hippuric acid, $\mathrm{Xa}=$ xanthine and hypoxanthine, Aa $=$ amino acids, Ue $=$ urea, Ua $=$ uric acid, and $\mathrm{Al}=$ allantoin

\section{The Database}

A review of the published literature on high-sugar grasses was conducted, and data were extracted from appropriate papers to create the independent database used for model evaluation in this study. The database comprised data (treatment means) from Miller et al. (2001a), Valk (2002), Tas et al. (2005, 2006a), and Moorby et al. (2006), with a total of 28 data points from these 4 sources. For the Valk (2002) data, required variables were obtained from various chapters of Valk's thesis: DMI and N excretion results were from chapter 5 a of Valk (2002), milk yield and composition were from Valk et al. (2000), and grass composition and measured degradability values were from Valk et al. (1996). The criterion for selection of suitable data from the literature was that the following information was available: observed $\mathrm{N}$ intake and $\mathrm{N}$ excretion (milk, feces), DMI, diet ingredients as a percentage of the total diet (used to estimate fractional degradation rates and missing variables), chemical composition of the total diet, both grass and grain (DMI, CP, NDF, WSC, starch, ash, crude fat), BW, milk yield, and milk composition. These data are required to run the model and evaluate performance objectively. Where information on the diet was missing, values were derived from feeding tables (Sauvant et al., 2004; CVB, 2007). Stringent selection procedures, set in place to minimize discrepancies between studies and their representation within the model, meant that the database was somewhat limited in size. A description of the database can be found in Table 1.

\section{Model Evaluation}

The model was evaluated for how well $\mathrm{N}$ excretion, NDF digestibility, and milk yield were predicted. These represent the available observed measures. Predictions were assessed using 2 methods. First, mean square prediction error (MSPE), calculated as

$$
\operatorname{MSPE}=\sum_{i=1}^{n}\left(O_{i}-P_{i}\right)^{2} / n
$$

where $O_{i}$ is the observed value, $P_{i}$ is the predicted value, and $n$ is the number of observations. The square root of the MSPE (RMSPE), expressed as a percentage of the observed mean, gives an estimate of the overall prediction error. The MSPE can be decomposed into random error (ED), error due to deviation of the regression slope from unity (ER), and error due to overall bias (ECT; Bibby and Toutenburg, 1977). Second, concordance correlation coefficient analysis (CCC) was performed (Lin, 1989), where CCC was calculated as

$$
\mathrm{CCC}=R \times C_{b},
$$


Table 1. Summary of literature database

\begin{tabular}{|c|c|c|c|}
\hline Variable & Mean $^{1}$ & Minimum & Maximum \\
\hline \multicolumn{4}{|l|}{ Animal } \\
\hline Milk yield $^{2}(\mathrm{~kg} / \mathrm{d})$ & $25.6( \pm 0.78)$ & 13.5 & 33.6 \\
\hline BW (kg) & $596( \pm 6.1)$ & 546 & 652 \\
\hline \multicolumn{4}{|l|}{ Diet } \\
\hline DMI (kg/d) & $18.2( \pm 0.34)$ & 14.2 & 21.5 \\
\hline Roughage $\%$ diet & $85( \pm 1.0)$ & 75 & 92 \\
\hline $\mathrm{CP}(\mathrm{g} / \mathrm{kg}$ of $\mathrm{DM})$ & $180( \pm 6.9)$ & 115 & 263 \\
\hline WSC (g/kg of DM) & $179( \pm 8.9)$ & 95 & 252 \\
\hline Starch $(\mathrm{g} / \mathrm{kg}$ of $\mathrm{DM})$ & $38( \pm 4.1)$ & 11 & 67 \\
\hline $\mathrm{NDF}(\mathrm{g} / \mathrm{kg}$ of DM) & $478( \pm 9.9)$ & 400 & 578 \\
\hline Lipid $(\mathrm{g} / \mathrm{kg}$ of $\mathrm{DM})$ & $24( \pm 0.2)$ & 23 & 26 \\
\hline Ash $(\mathrm{g} / \mathrm{kg}$ of $\mathrm{DM})$ & $101( \pm 2.5)$ & 63 & 120 \\
\hline WSC:CP ratio & $1.1( \pm 0.08)$ & 0.36 & 1.91 \\
\hline \multicolumn{4}{|l|}{ Nitrogen } \\
\hline $\mathrm{N}$ intake $(\mathrm{g} / \mathrm{d})$ & $525( \pm 22.2)$ & 279 & 817 \\
\hline Total N excretion $(\mathrm{g} / \mathrm{d})$ & $380( \pm 18.9)$ & 181 & 557 \\
\hline Fecal N (g/d) & $132( \pm 4.1)$ & 101 & 179 \\
\hline Milk N (g/d) & $123( \pm 3.4)$ & 68 & 147 \\
\hline Urine $N(\mathrm{~g} / \mathrm{d})$ & $248( \pm 16.9)$ & 71 & 393 \\
\hline Milk N:intake N ratio & $0.236( \pm 0.0082)$ & 0.173 & 0.310 \\
\hline
\end{tabular}

${ }^{1}$ Mean \pm standard error of the mean, from 28 data points from 4 sources: Moorby et al. (2006), Tas et al. (2005, 2006a), Miller et al. (2001a), and Valk (2002), and where diet variables represent the whole diet (grass + grain) and composition of grass and grain are adjusted so that CP, water-soluble carbohydrates (WSC), starch, NDF, lipid, and ash sum to $1,000 \mathrm{~g} / \mathrm{kg}$ of DM by dividing the unknown fraction between WSC and NDF for grass and between starch and NDF for grain.

${ }^{2}$ Corrected to $3.5 \%$ milk fat and $3.2 \%$ milk protein.

where $R$ is the Pearson correlation coefficient and $C_{b}$ is a bias correction factor. The $R$ variable gives a measure of precision, whereas $C_{b}$ is a measure of accuracy. An associated variable $\mu$ gives an indication of bias, where a positive value indicates under-prediction, and a negative value indicates over-prediction (Lin, 1989).

\section{Model Behavior Analysis}

To evaluate the behavior of the model given a wide variety of high-WSC grass compositions and feeding scenarios, the following simulations were performed. High-WSC grass simulations are presented in Table 2 and represent inputs for the model. The WSC fraction of grass $(\mathrm{g} / \mathrm{kg}$ of $\mathrm{DM})$ was increased by 3 levels: 20 , 60 , and $90 \mathrm{~g} / \mathrm{kg}$ of $\mathrm{DM}$ at the expense of $\mathrm{CP}, \mathrm{NDF}$, or a 50:50 split of CP and NDF. High and low basal $\mathrm{N}$ levels of the grass were simulated, representing high and low $\mathrm{N}$ fertilization levels, with $50 \mathrm{~g}$ of $\mathrm{CP} / \mathrm{kg}$ of DM difference between the $\mathrm{N}$ content of the grasses, roughly representing $\mathrm{N}$ fertilization levels of 300 and $450 \mathrm{~kg}$ of $\mathrm{N} /$ ha per year (e.g., see Valk et al., 2000). Dry matter intake was increased by $300 \mathrm{~g} / \mathrm{d}$ with the high $\mathrm{N}$ fertilized grass, to represent the observed relationship between $\mathrm{N}$ fertilization of grass and DMI (Valk et al., 2000). Simulations were done on $100 \%$ grass diets and an $89 \%$ grass diet (with the addition of $2 \mathrm{~kg} / \mathrm{d}$ of concentrate). Simulated concentrate composition was as follows: $19.5 \%$ wheat, $15 \%$ soybean meal, $15 \%$ sugar beet pulp, $13 \%$ palm kernel meal, $11 \%$ rapeseed meal, $9 \%$ maize gluten, $8 \%$ molasses, $7 \%$ sunflower meal, $1 \%$ vegetable oil, and $1 \%$ trace mineral mixture, on a DM basis. Chemical compositions of feed ingredients were derived from feed tables (Sauvant et al., 2004; CVB, 2007).

It was assumed that simulated cows had a BW of 596 $\mathrm{kg}$, produced milk with $4.21 \%$ fat, $3.31 \%$ protein, and $4.53 \%$ lactose, and had a DMI in the range of 16.0 to $18.3 \mathrm{~kg} / \mathrm{d}$ (see Table 2 for details). Values were based on the average of the literature database. Milk composition values were held constant based on the observation that in the literature data, milk composition did not differ significantly between high and low WSC diets (see Edwards et al., 2007 for a review). Degradation characteristics of the NDF and CP content of grasses, required for the model, were determined by simple regression analysis of the data of Valk et al. (1996), where

$$
\begin{gathered}
\mathrm{k}_{\mathrm{p}} \mathrm{CP}=[9.57 \times(\mathrm{CP} / \mathrm{NDF})+3.9] / 100\left(\mathrm{R}^{2}=0.507\right) \\
\mathrm{sCP}=0.0179 \times(\mathrm{CP} / \mathrm{NDF})+0.158\left(\mathrm{R}^{2}=0.002\right), \\
\mathrm{uCP}=-0.216 \times(\mathrm{CP} / \mathrm{NDF})+0.236\left(\mathrm{R}^{2}=0.694\right),
\end{gathered}
$$

$\mathrm{k}_{\mathrm{p}} \mathrm{NDF}=(-0.0175 \times \mathrm{NDF}+11.8) / 100\left(\mathrm{R}^{2}=0.334\right)$, 
Table 2. Summary of simulations

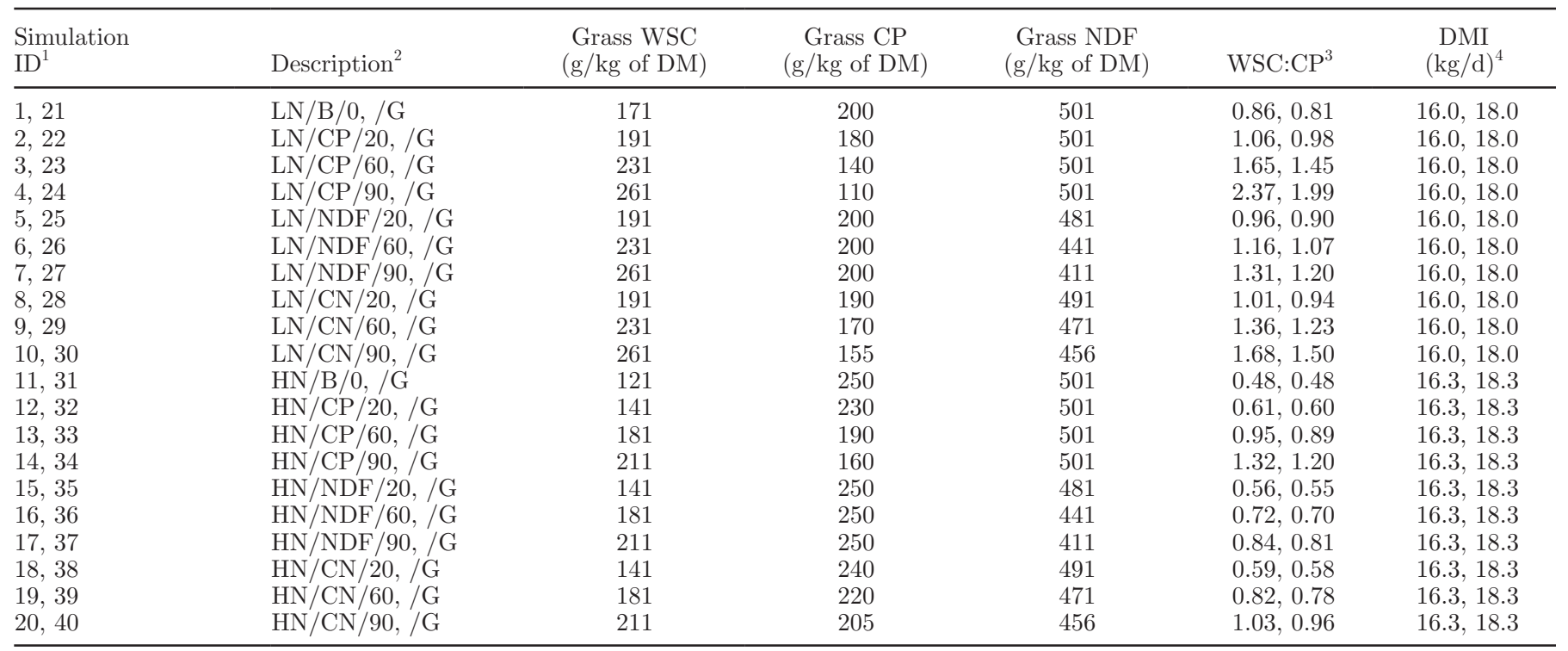

${ }^{1}$ Simulations 1-20 are $100 \%$ grass diets with DMI of 16.0 or $16.3 \mathrm{~kg}$ of DM/d; simulations $21-40$ are using the same grass as diets 1-20 but have an additional $2 \mathrm{~kg}$ of DM of concentrate fed per day. The concentrate composition, g/ $\mathrm{kg}$ of DM, was 195 wheat, 150 soybean meal, 150 sugar beet pulp, 130 palm kernel meal, 110 rapeseed meal, 90 maize gluten, 80 molasses, 70 sunflower meal, 10 vegetable oil, and 10 trace mineral mixture; $\mathrm{CP}=225, \mathrm{NDF}=336$, fat $=41$, water-soluble carbohydrate $(\mathrm{WSC})=107$, starch $=222$ and ash $=69$.

${ }^{2}$ Simulations 1-10 and 21-30 represent low N fertilized grass (LN), and simulations 11-20 and 31-40 represent high N fertilized grass (HN); B = basal WSC levels, and WSC increases at the expense of CP, NDF, or a 50:50 split of CP and NDF (CN); 20, 60, and 90 represent the level $(\mathrm{g} / \mathrm{kg}$ of DM) of trade with WSC as WSC of the grass increases; grain $(\mathrm{G})$ is fed in simulations 21-40.

${ }^{3} \mathrm{WSC}$ :CP ratio of the whole diet; corresponds to simulation ID information in footnotes 1 and 2.

${ }^{4}$ Corresponds to simulation ID information in footnotes 1 and 2.

$\mathrm{uNDF}=0.000367 \times \mathrm{NDF}-0.0162\left(\mathrm{R}^{2}=0.453\right),[8]$

where $\mathrm{k}_{\mathrm{p}} \mathrm{CP}$ and $\mathrm{k}_{\mathrm{p}} \mathrm{NDF}$ are the degradation rates $(/ \mathrm{h})$ of $\mathrm{CP}$ and $\mathrm{NDF}$, respectively; $\mathrm{sCP}$ is the washout $\mathrm{CP}$ fraction; $\mathrm{uCP}$ is the undegradable $\mathrm{CP}$ fraction; and $\mathrm{uNDF}$ is the undegradable NDF fraction; CP and NDF are in grams per kilogram of DM.

\section{RESULTS AND DISCUSSION}

\section{Model Evaluation}

Nitrogen Excretion. Results of MSPE and CCC analysis of $\mathrm{N}$ predictions on the literature database are presented in Table 3, and plots of the predicted versus observed $\mathrm{N}$ outputs are presented in Figure 2. Results of MSPE and CCC analysis show that urine $\mathrm{N}$, milk $\mathrm{N}$, and total $\mathrm{N}$ excretion $(\mathrm{g} / \mathrm{d})$ were predicted adequately by the model (RMSPE $=19.9,8.4$, and $10.4 \%$, respectively, and $\mathrm{CCC}=0.866,0.868,0.926$, respectively). Examination of the MSPE decomposition reveals that the error was divided between ECT, ER, and $\mathrm{ED}$, but that the majority of error was due to ED. From CCC analysis and visual examination of Figure 2, fecal $\mathrm{N}$ prediction contained substantially more random variation. Although the RMSPE value was comparable to that of urine $\mathrm{N}$ prediction, the $\mathrm{CCC}$ value was substantially lower $(\mathrm{CCC}=0.173)$.

The negative $\mu$ values in Table 3 for urine $\mathrm{N}$, fecal $\mathrm{N}$, and total $\mathrm{N}$ excretion indicate that the model has a tendency (herein tendency is used to describe a pattern or direction in the results, with no statistical implication) to over-predict these values, and the positive $\mu$ value for milk $\mathrm{N}$ indicates a tendency of the model to slightly under-predict this value. These trends are confirmed by examination of the observed and predicted means in Table 3. Overall, N excretion was predicted well by the model in terms of both the mean values and the slope within study.

Milk Yield. Results of MSPE and CCC analysis of milk yield predictions on the literature database are presented in Table 3, and the plot of predicted versus observed milk yield is presented in Figure 3. Results show that the model predicted fat- and protein-corrected milk yield well, with an RMSPE value of $11.5 \%$ and a CCC value of 0.728 . Predictions were generally good, except for a tendency for under-prediction on the Moorby et al. (2006) data. Under-prediction of milk yield in the Moorby et al. (2006) data can be partly attributed to the slight under-prediction of NDF digestibility for these data (Figure 4). However, the apparent under-prediction of NDF digestibility for the Tas et al. 
Table 3. Mean square prediction error and concordance correlation coefficient analysis results for N excretion, milk yield, and NDF digestibility, as predicted by the modified Dijkstra model

\begin{tabular}{|c|c|c|c|c|c|c|c|c|c|c|}
\hline \multirow[b]{2}{*}{ Variable } & \multirow[b]{2}{*}{$\begin{array}{c}\text { Observed } \\
\text { mean }\end{array}$} & \multirow[b]{2}{*}{$\begin{array}{l}\text { Predicted } \\
\text { mean }\end{array}$} & \multicolumn{8}{|c|}{ Parameter $^{1}$} \\
\hline & & & $\begin{array}{c}\text { RMSPE } \\
(\%)\end{array}$ & $\begin{array}{c}\mathrm{ECT} \\
(\%)\end{array}$ & $\begin{array}{l}\mathrm{ER} \\
(\%)\end{array}$ & $\begin{array}{l}\mathrm{ED} \\
(\%)\end{array}$ & $\mathrm{CCC}$ & $\mathrm{R}$ & $\mathrm{C}_{\mathrm{b}}$ & $\mu$ \\
\hline Urine $N(\mathrm{~g} / \mathrm{d})$ & $248( \pm 16.9)$ & $261( \pm 19.4)$ & 19.9 & 7.2 & 22.7 & 70.1 & 0.866 & 0.882 & 0.981 & -0.140 \\
\hline Fecal N (g/d) & $132( \pm 4.1)$ & $143( \pm 3.2)$ & 20.2 & 18.5 & 21.1 & 60.4 & 0.173 & 0.210 & 0.823 & -0.610 \\
\hline Milk N (g/d) & $123( \pm 3.4)$ & $121( \pm 4.3)$ & 8.4 & 2.6 & 38.4 & 59.0 & 0.868 & 0.893 & 0.971 & 0.084 \\
\hline Total N excretion $(\mathrm{g} / \mathrm{d})$ & $380( \pm 18.9)$ & $404( \pm 20.1)$ & 10.4 & 38.9 & 7.34 & 53.7 & 0.926 & 0.955 & 0.969 & -0.244 \\
\hline
\end{tabular}

${ }^{1} \mathrm{RMSPE}=$ root mean square prediction error expressed as a percentage of the observed mean; ECT $=$ error due to bias (\% of total MSPE); ER $=$ error due to regression ( $\%$ of total MSPE); ED = error due to disturbance ( $\%$ of total MSPE); CCC = concordance correlation coefficient, where $\mathrm{CCC}=\mathrm{R} \times \mathrm{C}_{\mathrm{b}}$, and $\mathrm{R}=$ Pearson correlation coefficient and $\mathrm{C}_{\mathrm{b}}=$ bias correction factor; and $\mu=$ location shift.

${ }^{2}$ Corrected to $3.5 \%$ milk fat and $3.2 \%$ milk protein.
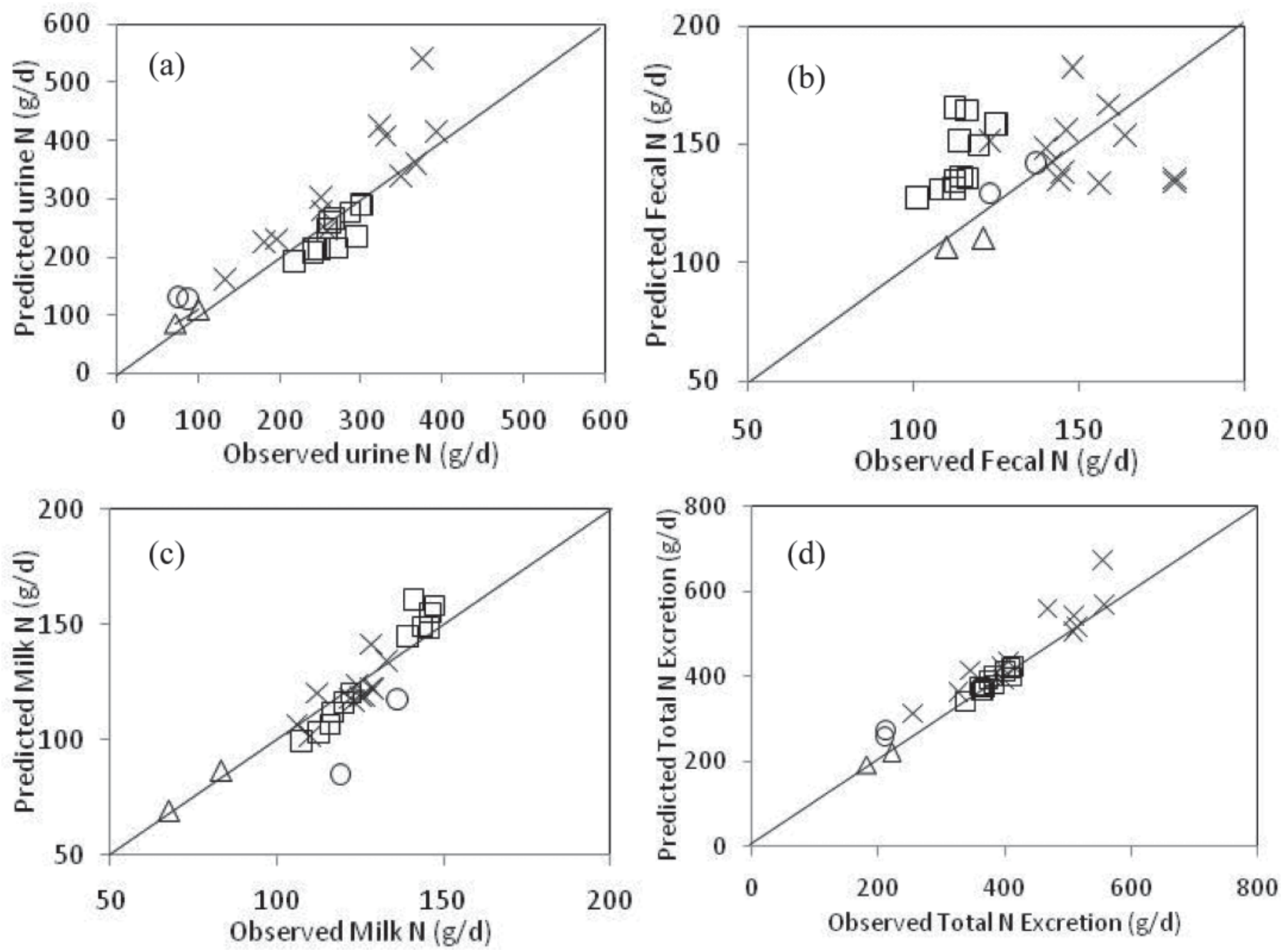

Figure 2. Predicted versus observed urine N (a), fecal N (b), milk N (c), and total N (d) excretion from the modified Dijkstra model, where $\times=$ Valk (2002) data, $\Delta=$ Miller et al. (2001a) data, $\bigcirc=$ Moorby et al. (2006) data, and $\square=$ Tas et al. (2005, 2006a) data. 


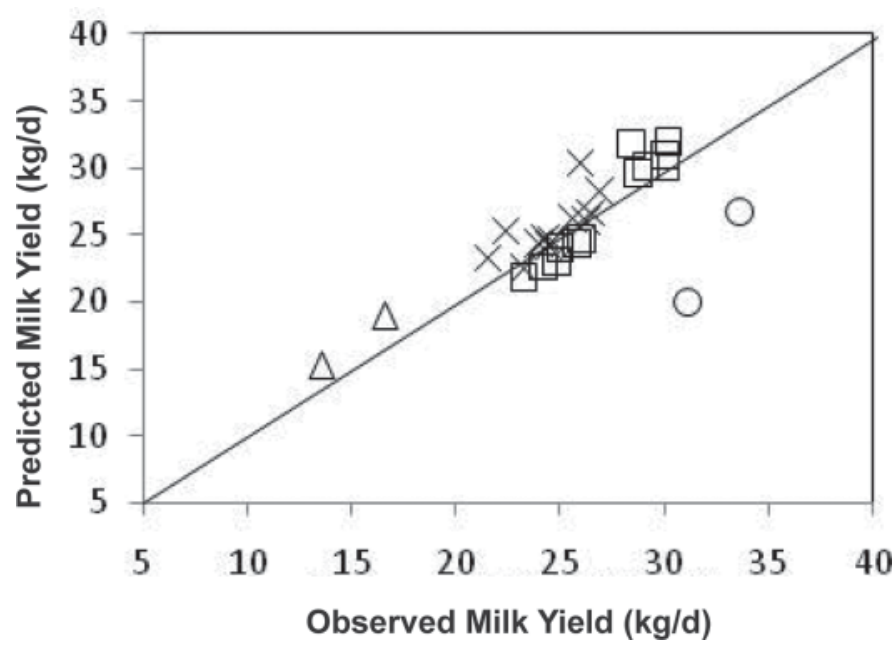

Figure 3. Predicted versus observed milk yield $(\mathrm{kg} / \mathrm{d})$, where $\times=$ Valk (2002) data, $\Delta=$ Miller et al. (2001a) data, $\bigcirc=$ Moorby et al. (2006) data, and $\square=$ Tas et al. (2005, 2006a) data. For all studies, milk yields were corrected to milk containing $3.5 \%$ milk fat and $3.2 \%$ milk protein.

$(2005,2006 a)$ year 2000 data does not carry through to the milk yield predictions. This suggests that a problem might exist with the observed year 2000 NDF digestibility data from Tas et al. (2005, 2006a).

NDF Digestibility. Results of MSPE and CCC analysis of NDF digestibility predictions on the literature database are presented in Table 3 , and the plot of predicted versus observed NDF digestibility is presented in Figure 4. Whole-tract NDF digestibility was predicted by the model with an RMSPE value of $11.3 \%$, with $50.4 \%$ of that error coming from random sources, and a CCC value of 0.087 . The positive $\mu$ value in Table 3 indicates a tendency for the model to under-predict NDF digestibility, although this result was largely influenced by the severe under-prediction of the year 2000 data by Tas et al. (2005, 2006a). The differences between the 2 years of data from Tas et al. are largely just DMI, which is higher on average in the under-predicted cluster of data (year 2000). Although the model indicated a decreased NDF digestibility on the higher DMI, this trend was not observed in the experimental results.

Overall, $\mathrm{N}$ predictions by the model follow the pattern and scale of observed results published in the literature and suggest that the model does an adequate job describing the changes in rumen fermentation and metabolism during control and high-WSC grass feeding scenarios.

\section{Behavioral Analysis}

In the previous section, the model was proven to follow patterns in observed $\mathrm{N}$ excretion, milk yield, and
NDF digestibility when high-WSC grasses are fed to cattle. The next step was to systematically examine the behavior of the model for precisely defined grass composition scenarios. Simulations performed are defined in Table 2, and the $\mathrm{N}$ simulation results are presented in Tables 4 and 5 .

Nitrogen Excretion. Across all high-WSC grass scenarios, the $\mathrm{N}$ utilization ratio (milk $\mathrm{N}, \%$ of intake $\mathrm{N}$ ) increased as the WSC content of grass increased. However, this occurred to varying degrees depending on the WSC scenario examined (Tables 4 and 5). The $\mathrm{N}$ utilization ratio tended to increase most $(\sim 94 \%$ increase) when WSC increased at the expense of CP, followed by a trade with both $\mathrm{CP}$ and NDF $(\sim 50 \%$ increase), and finally by a trade with NDF $(\sim 21 \%$ increase).

WSC Increases at the Expense of CP. Results from Tables 4 and 5 show that, as expected, urine $\mathrm{N}$ (g/d and \% of $\mathrm{N}$ intake) decreased most dramatically when WSC increased at the expense of CP. Miller et al. (2000), who fertilized control grass with extra N to amplify the difference between the control and high-WSC grasses, also found that urine $\mathrm{N}$ was a significantly smaller proportion of $\mathrm{N}$ intake in the high-WSC grass compared with the control. However, both with predictions and observations, the lower urine $\mathrm{N}$ content can be related to the lower total $\mathrm{N}$ intake in the high-WSC grass compared with the control and is likely the major causal factor. Fecal N (g/d) also decreased, but fecal N (\% of $\mathrm{N}$ intake) increased due to the decline of dietary $\mathrm{N}$ intake $(\mathrm{g} / \mathrm{d})$ and the associated decrease in $\mathrm{CP}$ digestibility (Tables 6 and 7). Overall, total $\mathrm{N}$ excretion

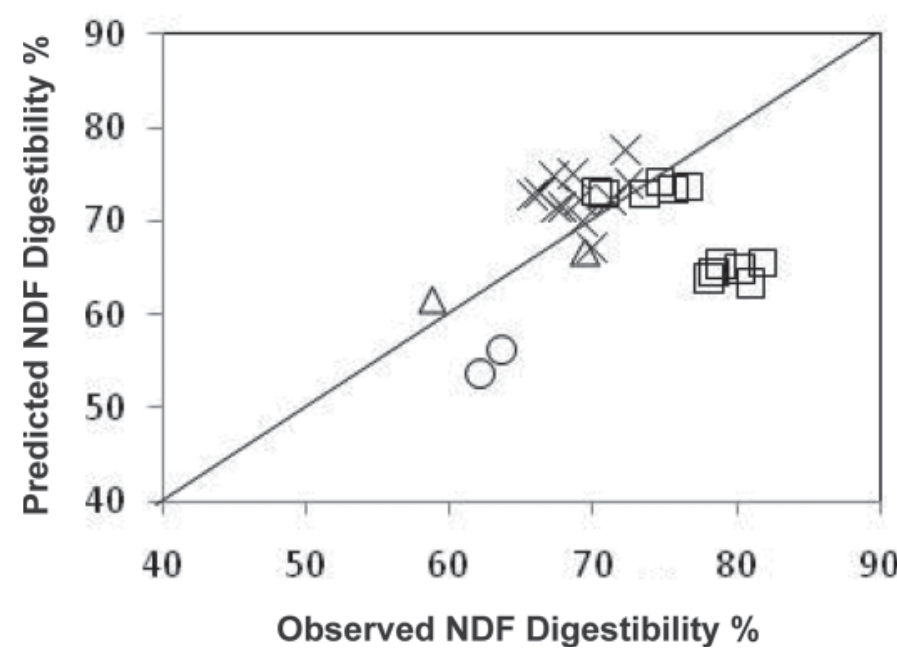

Figure 4. Predicted versus observed whole-tract NDF digestibility, where $\times=$ Valk (2002) data, $\Delta=$ Miller et al. (2001a) data, $\mathrm{O}$ $=$ Moorby et al. (2006) data, and $\square=$ Tas et al. (2005, 2006a) data. 
Table 4. Summary of simulated N excretion without grain feeding

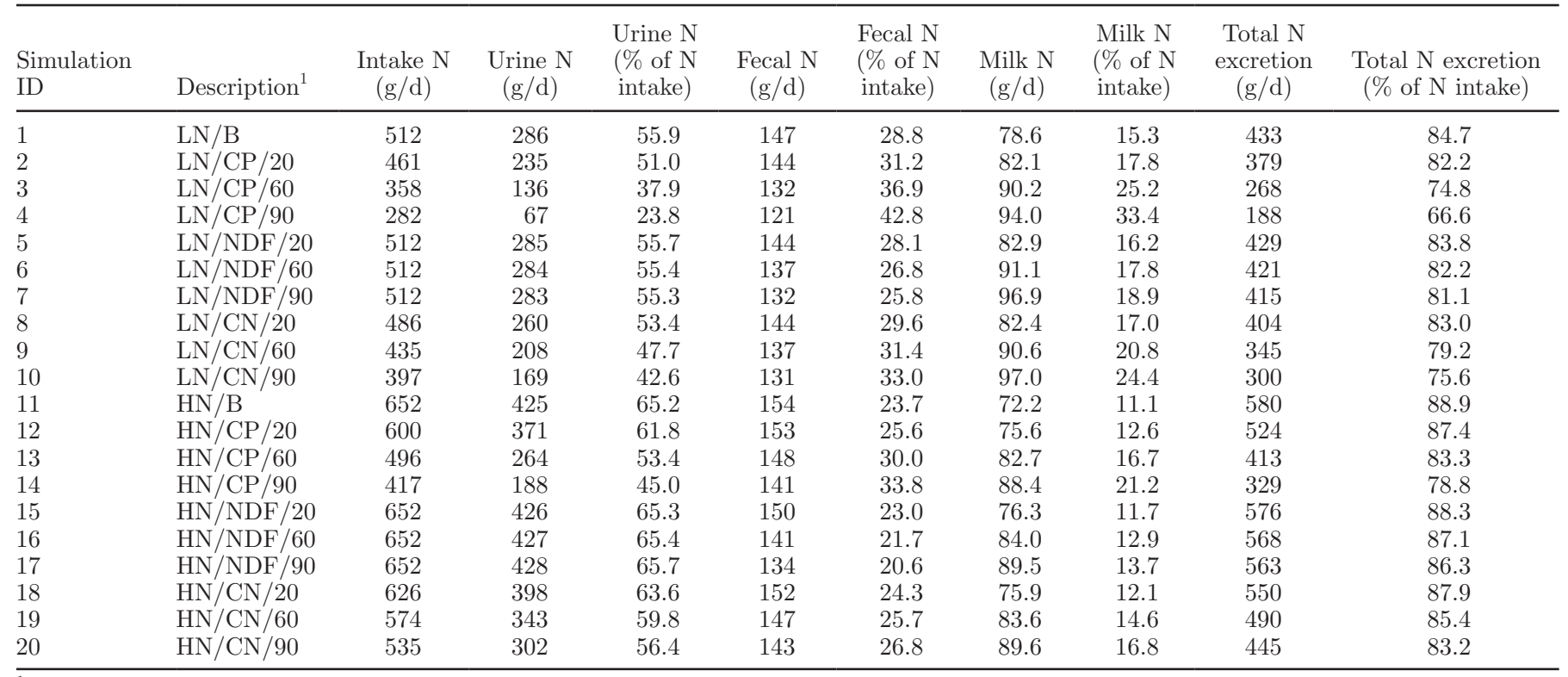

${ }^{1} \mathrm{LN}=$ low $\mathrm{N}$ fertilized grass; HN = high $\mathrm{N}$ fertilized grass; $\mathrm{B}=$ basal water-soluble carbohydrate (WSC) levels, and WSC increases at the expense of $\mathrm{CP}, \mathrm{NDF}$, or a 50:50 split of $\mathrm{CP}$ and $\mathrm{NDF}(\mathrm{CN}) ; 20,60$, and 90 represent the level (g/kg of DM) of trade with WSC as WSC of the grass increases.

(expressed both in $\mathrm{g} / \mathrm{d}$ and $\%$ of $\mathrm{N}$ intake) declines as WSC increases at the expense of CP (Tables 4 and 5).

WSC Increases at the Expense of NDF. As WSC increased at the expense of NDF in grass, the model predicted that urine $\mathrm{N}$ (both $\mathrm{g} / \mathrm{d}$ and $\%$ of $\mathrm{N}$ intake) decreased only slightly (Tables 4 and 5 ). Fecal N (g/d and $\%$ of $\mathrm{N}$ intake) decreased, overall total $\mathrm{N}$ excretion decreased slightly, and milk $\mathrm{N}$ increased. These results are of a lower magnitude than the results of Moorby et al. (2006) who observed much larger decreases in urine $\mathrm{N}$ when WSC increased at the expense of mainly NDF. However, Moorby et al. (2006) also used extremely low CP grass (for which amplified results have been suggested, see Edwards et al., 2007) and reported a

Table 5. Summary of simulated N excretion with grain feeding

\begin{tabular}{|c|c|c|c|c|c|c|c|c|c|c|}
\hline $\begin{array}{l}\text { Simulation } \\
\text { ID }\end{array}$ & Description $^{1}$ & $\begin{array}{l}\text { Intake } \\
\mathrm{N}(\mathrm{g} / \mathrm{d})\end{array}$ & $\begin{array}{l}\text { Urine } \\
\mathrm{N}(\mathrm{g} / \mathrm{d})\end{array}$ & $\begin{array}{l}\text { Urine } \mathrm{N} \\
(\% \text { of } \mathrm{N} \\
\text { intake) }\end{array}$ & $\begin{array}{l}\text { Fecal N } \\
(\mathrm{g} / \mathrm{d})\end{array}$ & $\begin{array}{l}\text { Fecal N } \\
(\% \text { of } \mathrm{N} \\
\text { intake) }\end{array}$ & $\begin{array}{c}\text { Milk N } \\
(\mathrm{g} / \mathrm{d})\end{array}$ & $\begin{array}{l}\text { Milk } \mathrm{N} \\
(\% \text { of } \mathrm{N} \\
\text { intake) }\end{array}$ & $\begin{array}{c}\text { Total N } \\
\text { excretion } \\
(\mathrm{g} / \mathrm{d})\end{array}$ & $\begin{array}{c}\text { Total N } \\
\text { excretion } \\
(\% \text { of } \mathrm{N} \text { intake })\end{array}$ \\
\hline 21 & $\mathrm{LN} / \mathrm{B} / \mathrm{G}$ & 583 & 323 & 55.4 & 162 & 27.8 & 98 & 16.8 & 485 & 83.2 \\
\hline 22 & $\mathrm{LN} / \mathrm{CP} / 20 / \mathrm{G}$ & 533 & 272 & 51.1 & 159 & 29.8 & 102 & 19.1 & 431 & 80.9 \\
\hline 23 & $\mathrm{LN} / \mathrm{CP} / 60 / \mathrm{G}$ & 430 & 172 & 39.9 & 149 & 34.7 & 109 & 25.4 & 321 & 74.6 \\
\hline 24 & $\mathrm{LN} / \mathrm{CP} / 90 / \mathrm{G}$ & 353 & 100 & 28.2 & 139 & 39.5 & 114 & 32.3 & 239 & 67.7 \\
\hline 25 & $\mathrm{LN} / \mathrm{NDF} / 20 / \mathrm{G}$ & 583 & 321 & 55.1 & 160 & 27.4 & 102 & 17.6 & 481 & 82.4 \\
\hline 26 & $\mathrm{LN} / \mathrm{NDF} / 60 / \mathrm{G}$ & 583 & 319 & 54.7 & 154 & 26.4 & 111 & 19.0 & 473 & 81.0 \\
\hline 27 & $\mathrm{LN}^{\prime} / \mathrm{NDF} / 90 / \mathrm{G}$ & 583 & 317 & 54.4 & 149 & 25.6 & 117 & 20.0 & 467 & 80.0 \\
\hline 28 & $\mathrm{LN} / \mathrm{CN} / 20 / \mathrm{G}$ & 558 & 296 & 53.1 & 159 & 28.6 & 102 & 18.3 & 456 & 81.7 \\
\hline 29 & $\mathrm{LN} / \mathrm{CN} / 60 / \mathrm{G}$ & 508 & 244 & 48.0 & 154 & 30.3 & 110 & 21.7 & 397 & 78.3 \\
\hline 30 & $\mathrm{LN} / \mathrm{CN} / 90 / \mathrm{G}$ & 468 & 203 & 43.3 & 149 & 31.8 & 117 & 24.9 & 351 & 75.1 \\
\hline 31 & $\mathrm{HN} / \mathrm{B} / \mathrm{G}$ & 725 & 464 & 64.0 & 169 & 23.4 & 91 & 12.6 & 633 & 87.4 \\
\hline 32 & $\mathrm{HN} / \mathrm{CP} / 20 / \mathrm{G}$ & 672 & 409 & 60.8 & 168 & 25.1 & 95 & 14.1 & 577 & 85.9 \\
\hline 33 & $\mathrm{HN} / \mathrm{CP} / 60 / \mathrm{G}$ & 567 & 302 & 53.2 & 164 & 28.9 & 102 & 18.0 & 465 & 82.0 \\
\hline 34 & $\mathrm{HN} / \mathrm{CP} / 90 / \mathrm{G}$ & 489 & 223 & 45.7 & 157 & 32.2 & 108 & 22.1 & 381 & 77.9 \\
\hline 35 & $\mathrm{HN} / \mathrm{NDF} / 20 / \mathrm{G}$ & 725 & 464 & 64.0 & 165 & 22.8 & 95 & 13.2 & 629 & 86.8 \\
\hline 36 & $\mathrm{HN} / \mathrm{NDF} / 60 / \mathrm{G}$ & 725 & 464 & 64.1 & 157 & 21.7 & 103 & 14.3 & 621 & 85.7 \\
\hline 37 & $\mathrm{HN} / \mathrm{NDF} / 90 / \mathrm{G}$ & 725 & 465 & 64.2 & 150 & 20.8 & 109 & 15.0 & 616 & 85.0 \\
\hline 38 & $\mathrm{HN} / \mathrm{CN} / 20 / \mathrm{G}$ & 697 & 435 & 62.4 & 167 & 23.9 & 95 & 13.6 & 602 & 86.4 \\
\hline 39 & $\mathrm{HN} / \mathrm{CN} / 60 / \mathrm{G}$ & 646 & 380 & 58.8 & 163 & 25.2 & 103 & 16.0 & 543 & 84.0 \\
\hline 40 & $\mathrm{HN} / \mathrm{CN} / 90 / \mathrm{G}$ & 608 & 339 & 55.8 & 159 & 26.2 & 109 & 18.0 & 498 & 82.0 \\
\hline
\end{tabular}

${ }^{1} \mathrm{LN}=$ low $\mathrm{N}$ fertilized grass; HN = high $\mathrm{N}$ fertilized grass; $\mathrm{B}=$ basal water-soluble carbohydrate (WSC) levels, and WSC increases at the

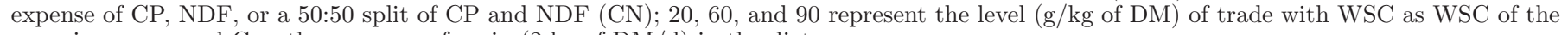
grass increases; and $\mathrm{G}=$ the presence of grain $(2 \mathrm{~kg}$ of $\mathrm{DM} / \mathrm{d})$ in the diet. 
Table 6. Summary of simulated milk yield, digestibility values, and predicted rumen $\mathrm{pH}$ without grain feeding

\begin{tabular}{|c|c|c|c|c|c|c|}
\hline $\begin{array}{l}\text { Simulation } \\
\text { ID }\end{array}$ & Description $^{1}$ & $\begin{array}{l}\text { Milk yield }^{2} \\
\quad(\mathrm{~kg} / \mathrm{d})\end{array}$ & $\begin{array}{c}\text { NDF } \\
\text { digestibility (\%) }\end{array}$ & $\begin{array}{c}\mathrm{CP} \\
\text { digestibility (\%) }\end{array}$ & $\begin{array}{c}\text { Starch } \\
\text { digestibility (\%) }\end{array}$ & $\mathrm{pH}$ \\
\hline 1 & $\mathrm{LN} / \mathrm{B}$ & 20.9 & 74.1 & 73.0 & 97.5 & 5.99 \\
\hline 2 & $\mathrm{LN} / \mathrm{CP} / 20$ & 20.7 & 72.7 & 70.8 & 97.5 & 5.98 \\
\hline 4 & $\mathrm{LN} / \mathrm{CP} / 90$ & 19.9 & 64.7 & 60.1 & 97.3 & 5.97 \\
\hline 5 & $\mathrm{LN} / \mathrm{NDF} / 20$ & 21.4 & 75.1 & 73.7 & 97.6 & 5.97 \\
\hline 6 & $\mathrm{LN} / \mathrm{NDF} / 60$ & 22.4 & 76.7 & 74.9 & 97.7 & 5.94 \\
\hline 10 & $\mathrm{LN} / \mathrm{CN} / 90$ & 21.5 & 72.1 & 69.2 & 97.7 & 5.94 \\
\hline 11 & $\mathrm{HN} / \mathrm{B}$ & 22.2 & 76.6 & 77.7 & 97.2 & 5.99 \\
\hline 12 & $\mathrm{HN} / \mathrm{CP} / 20$ & 21.9 & 75.6 & 76.0 & 97.4 & 5.99 \\
\hline 13 & $\mathrm{HN} / \mathrm{CP} / 60$ & 21.4 & 73.2 & 72.0 & 97.5 & 5.98 \\
\hline 14 & $\mathrm{HN} / \mathrm{CP} / 90$ & 21.0 & 70.5 & 68.4 & 97.6 & 5.97 \\
\hline 15 & $\mathrm{HN} / \mathrm{NDF} / 20$ & 22.7 & 77.6 & 78.4 & 97.4 & 5.97 \\
\hline
\end{tabular}

${ }^{1} \mathrm{LN}=$ low $\mathrm{N}$ fertilized grass; $\mathrm{HN}=$ high $\mathrm{N}$ fertilized grass; $\mathrm{B}=$ basal water-soluble carbohydrate (WSC) levels, and WSC increases at the expense of $\mathrm{CP}, \mathrm{NDF}$, or a 50:50 split of $\mathrm{CP}$ and $\mathrm{NDF}(\mathrm{CN}) ; 20,60$, and 90 represent the level $(\mathrm{g} / \mathrm{kg}$ of DM) of trade with WSC as WSC of the grass increases.

${ }^{2}$ Corrected to $3.5 \%$ milk fat and $3.2 \%$ milk protein.

significant increase in DMI that was not represented here (DMI was held constant), which in combination, may account for the differences.

WSC Increases at the Expense of CP and NDF. When WSC increased at the expense of a combination of both $\mathrm{CP}$ and NDF, the simulated results were inter- mediary to the previous 2 scenarios (Tables 4 and 5). Urine $\mathrm{N}$ (both as $\mathrm{g} / \mathrm{d}$ and as a \% of $\mathrm{N}$ intake) declined as the WSC content increased. Fecal N (g/d) decreased, whereas fecal $\mathrm{N}$ (\% of $\mathrm{N}$ intake) increased slightly due to the decrease in $\mathrm{N}$ intake and intermediary change in $\mathrm{CP}$ digestibility compared with the other scenarios

Table 7. Summary of simulated milk yield, digestibility values, and predicted rumen $\mathrm{pH}$ with grain feeding

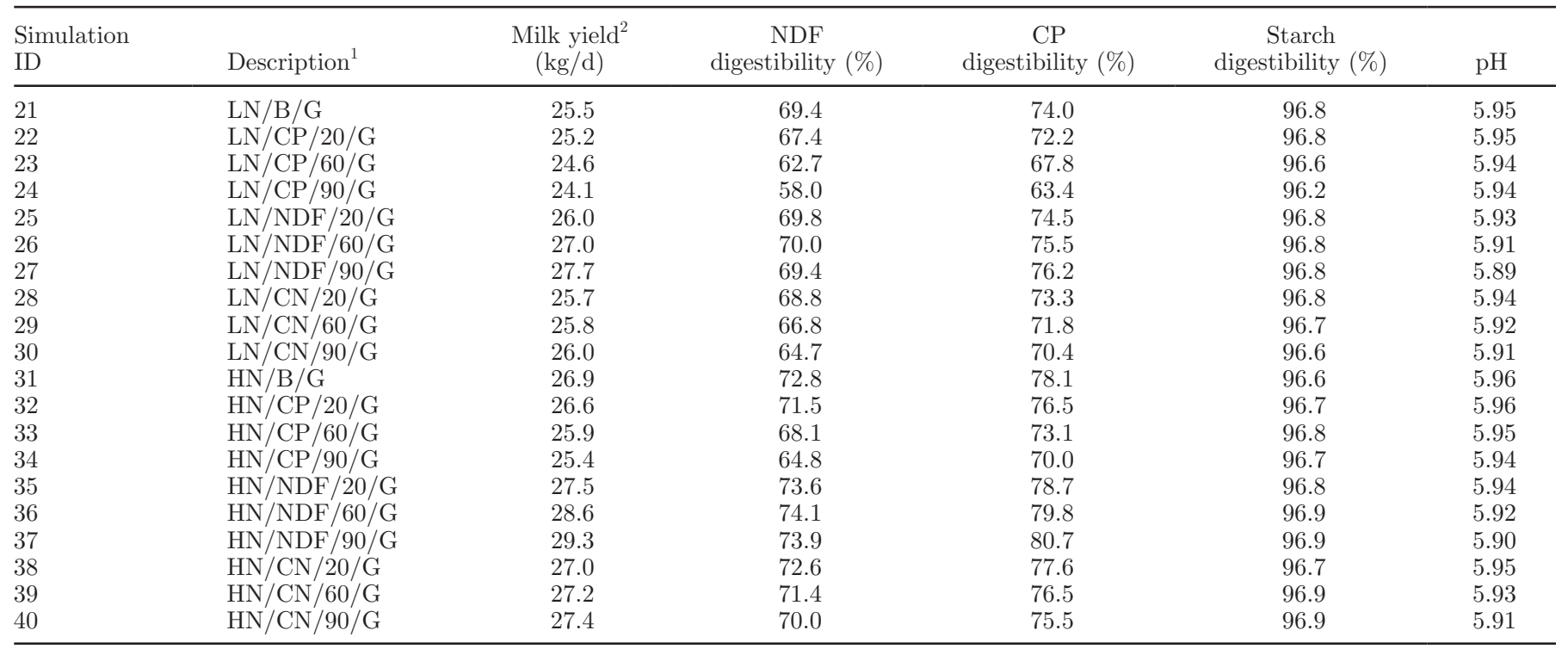

${ }^{1} \mathrm{LN}=$ low $\mathrm{N}$ fertilized grass; HN = high $\mathrm{N}$ fertilized grass; $\mathrm{B}=$ basal water-soluble carbohydrate (WSC) levels, and WSC increases at the expense of CP, NDF, or a 50:50 split of CP and NDF (CN); 20, 60, and 90 represent the level (g/kg of DM) of trade with WSC as WSC of the grass increases; and $\mathrm{G}=$ the presence of grain $(2 \mathrm{~kg}$ of $\mathrm{DM} / \mathrm{d})$ in the diet.

${ }^{2}$ Corrected to $3.5 \%$ milk fat and $3.2 \%$ milk protein. 
(Tables 6 and 7). Overall, total $\mathrm{N}$ excretion decreased and milk N increased. Miller et al. (2001a), who examined high-WSC grass that increased at the expense of a mix of $\mathrm{CP}$ and $\mathrm{NDF}$, reported a comparable decrease in urine $\mathrm{N}$; however, they also observed an increase in NDF digestibility with the high-WSC grass as opposed to the slight decrease predicted by the model. However, in Miller et al. (2001a), the CP:NDF split was weighted heavily toward NDF (decrease in $\mathrm{CP}$ was nonsignificant), and in the comparable scenario modeled here (trade with NDF), NDF digestibility also increased. On the other hand, Tas et al. (2005, 2006a) concluded that "no differences among cultivars were found in the excretion of $\mathrm{N}$ in milk (in $\mathrm{g} / \mathrm{d}$ or as a $\%$ of $\mathrm{N}$ intake)" and no significant effects on $\mathrm{N}$ use efficiency were observed when WSC increased at the expense of both $\mathrm{CP}$ and $\mathrm{NDF}$. The reduction in urine $\mathrm{N}$ was attributed to a lower intake of $\mathrm{N}$ in the high-WSC grasses. However, our model also predicts minimal change in $\mathrm{N}$ excretion or NDF and CP digestibility with high-WSC grasses at the level of DM exchange in the Tas et al. (2005, 2006a) data, which is, at times, toward the lower end (15-45 $\mathrm{g} / \mathrm{kg}$ of DM exchange), and this will have contributed to the lack of observed response (Tables 4 and 5). A similar lack of response was observed by Taweel et al. (2005a,b) and Tas et al. (2006b), but again, low levels of DM exchange were observed (approximately 20-40 $\mathrm{g} / \mathrm{kg}$ of DM).

Milk Yield. Much inconsistency exists in published results in terms of the effect of high WSC grasses on milk yield. Therefore, this paper also aimed to systematically examine predicted milk yield in the model, in an attempt to lend insight into published literature data.

WSC Increases at the Expense of CP. The model predicts that as WSC increases at the expense of $\mathrm{CP}$, milk yield has a slight tendency to decline regardless of whether the grass has been fertilized with extra $\mathrm{N}$ or not, and whether or not additional grain is fed. The magnitude of the decline increases with the degree of DM exchanged, up to $\sim 1 \mathrm{~kg} / \mathrm{d}$ when $100 \%$ grass was fed, or $\sim 1.5 \mathrm{~kg} / \mathrm{d}$ when grain was added to the diet at the $90 \mathrm{~g} / \mathrm{kg}$ of DM exchange level (Tables 6 and 7; simulations 1-4, 11-14, 21-24, and 31-34). Under this grass composition scenario, according to the model, energy was predicted to be the limiting factor for milk production, and the slight decline in predicted milk production was partially contributed to by a decline in NDF and CP digestibility as the CP content of the grass declines. Valk et al. (1996) observed this decline in NDF and CP digestibility with decline of CP content of grass, along with the slight decrease in milk yield.

In an attempt to accentuate the differences between high- and low-WSC variety grasses, and create a wider range of WSC:CP ratio to test "proof of concept", Miller et al. (2000) fertilized the control grasses with extra N 3 wk before harvest. This resulted in a low WSC content for control grasses, with WSC content being 194 versus $234 \mathrm{~g} / \mathrm{kg}$ of DM, and a CP content of 145 versus $107 \mathrm{~g} / \mathrm{kg}$ of DM, respectively. The NDF content of the grass did not differ (478 versus $480 \mathrm{~g} / \mathrm{kg}$ of DM for high-WSC and control grasses, respectively). Despite differences in sugar content, milk yield did not differ significantly between control and high-WSC cultivars (21.9 vs. $21.4 \mathrm{~kg}$ milk/d, respectively), although a slight numerical decline in milk yield was observed. With increases in WSC at the expense of $\mathrm{CP}$ at the 20 or $60 \mathrm{~g} / \mathrm{kg}$ of DM level with low $\mathrm{N}$ fertilization [average close to the Miller et al. (2000) data where $40 \mathrm{~g} / \mathrm{kg}$ of DM is exchanged], predicted milk yield decreased 0.3 to $0.9 \mathrm{~kg} / \mathrm{d}$ (Table 7; simulations 21 vs. 22 and 23), which is in line with the results of Miller et al. (2000) that showed a $0.5 \mathrm{~kg} / \mathrm{d}$ decline. Although Miller et al. (2000) observed no significant difference in NDF digestibility, a 2-percentage-unit numerical decline was observed (76 vs. $74 \%$ for control and high-WSC grass, respectively), which is in line with the 2- to 2.3-percentage-unit decline predicted by the model (Table 7 , simulations 21 vs. 22 and 23). This observational data hence seem to be in support of the slight decline in predicted milk yield when WSC increases at the expense of CP.

WSC Increases at the Expense of both CP and $\boldsymbol{N D F}$. When WSC in grass increased at the expense of a 50:50 split of both CP and NDF, predicted milk yield increased with a maximum of $0.6 \mathrm{~kg} / \mathrm{d}$ at an exchange level of $90 \mathrm{~g} / \mathrm{kg}$ of DM (Tables 6 and 7). The NDF and $\mathrm{CP}$ digestibilities decreased slightly, representing the intermediate between the predicted decrease when WSC is traded for CP and the predicted increase when WSC is traded for NDF.

In the studies by Tas et al. (2005, 2006a), the WSC content of grass was increased at the expense of both CP and NDF, depending on the cultivar and year. In the 2000 data, Latin square 1 (cultivars 1-3, where cultivar 1 was labeled as a high-WSC variety), WSC increased from 158.1 to $192.3 \mathrm{~g} / \mathrm{kg}$ of DM at the expense of NDF (decreased from 414.3 to $399.0 \mathrm{~g} / \mathrm{kg}$ of $\mathrm{DM}$ ) but also some CP (decreased from 166.2 to $160.2 \mathrm{~g} / \mathrm{kg}$ of DM). In Latin square 2 (cultivars 4-6, where cultivar 6 was labeled as a high-WSC variety), WSC increased from 151.7 to $195.3 \mathrm{~g} / \mathrm{kg}$ of DM, again at the expense of NDF (decreased from 428.7 to $400.4 \mathrm{~g} / \mathrm{kg}$ of $\mathrm{DM}$ ) and some CP (decreased from 158.6 to $150.4 \mathrm{~g} / \mathrm{kg}$ of DM). In the 2001 data, Latin square 1 (cultivars 1-3), WSC content increased from 92.5 to $130.7 \mathrm{~g} / \mathrm{kg}$ of DM, mostly at the expense of NDF (decreased from 462.5 to $420.0 \mathrm{~g} / \mathrm{kg}$ of DM), and CP actually increased slightly from 194.2 to $204.3 \mathrm{~g} / \mathrm{kg}$ of DM. In Latin square 2 (cultivars $4-6$ ), 
WSC increased from 98.4 to $112.8 \mathrm{~g} / \mathrm{kg}$ of $\mathrm{DM}$ at the expense of CP (decreased from 203.0 to $190.0 \mathrm{~g} / \mathrm{kg}$ of $\mathrm{DM}$ ), and NDF actually increased from 437.4 to 456.8 $\mathrm{g} / \mathrm{kg}$ of DM. Across cultivar and year, DMI and milk yield were largely not affected by increasing the WSC content of grass in the Tas et al. (2005, 2006a) data. Similarly, DM, OM, NDF, and CP digestibility did not differ in the Tas data, although they did increase in cultivars 1 to 3 in 2001 with the increase in WSC content, which is contradictory to the model results but could be due to the fact that $\mathrm{CP}$ actually increased as WSC increased in these specific cultivars.

The 2000 Tas data (Tas et al., 2005, 2006a), in which both NDF and CP are decreasing as WSC increases, most closely match simulations 28 and 29 (Table 7), in which WSC increases at the expense of a 50:50 split of NDF and CP between the range of 20 to $60 \mathrm{~g} / \mathrm{kg}$ of DM exchange. In these simulations, milk yield largely stayed the same (increases $0.2-0.3 \mathrm{~kg} / \mathrm{d}$ ) and NDF digestibility decreased slightly $(0.6-2.4 \%)$, as did CP digestibility (0.7-2.2\%).

Miller et al. (2001a) observed a significant $2.7 \mathrm{~kg} / \mathrm{d}$ increase in milk (and no significant effect on milk composition) when the WSC content of grass was increased from 126 to $165 \mathrm{~g} / \mathrm{kg}$ of $\mathrm{DM}(39 \mathrm{~g} / \mathrm{kg}$ of DM) at the expense of a small decline in CP $(14 \mathrm{~g} / \mathrm{kg}$ of DM; not significantly different in $\mathrm{N}$ intake) relative to a larger decline in NDF (45 g/ $\mathrm{kg}$ of DM). In this study total DMI did not differ significantly between high WSC and control grass cultivars, similar to the simulations results in the present study, but DM digestibility was significantly higher in the high WSC cultivar (71 vs. 64\%), and Miller et al. (2001a) concluded that the higher milk yield arose from an increased DM digestibility. Model predictions indicated an increased milk yield of 0.5 to $1.5 \mathrm{~kg} / \mathrm{d}$ for WSC increasing at the expense of NDF at the 20 and $60 \mathrm{~g} / \mathrm{kg}$ of DM exchange level (simulations 25 and 26). The extreme increase in digestibility observed was not reproduced by the model. The much larger increase in observed DM digestibility accounts for the proportionally higher increase in observed milk yield compared with the more conservative model predictions. The background for such a large increase in DM digestibility is not clear but could be attributed to a specific cultivar effect. It has not been observed in other studies.

WSC Increases at the Expense of NDF. With an increase of WSC at the expense of NDF, predicted milk yield increased up to $2.4 \mathrm{~kg} / \mathrm{d}$, and NDF and CP digestibility increased marginally (Tables 6 and 7).

Moorby et al. (2006) achieved an elevated WSC content grass by cutting the control grass in the morning and the high-WSC grass in the afternoon, resulting in WSC contents of 161 and $243 \mathrm{~g} / \mathrm{kg}$ of DM $(82 \mathrm{~g} /$ $\mathrm{kg}$ of DM difference), respectively. The WSC content increased largely at the expense of NDF $(83 \mathrm{~g} / \mathrm{kg}$ of DM decline) accompanied by an increase of CP content (104 vs. $99 \mathrm{~g} / \mathrm{kg}$ of DM). Milk yield was not significantly affected by dietary treatment despite higher DMI and DM digestibility. However, milk yield did increase numerically from 30.4 to $32.7 \mathrm{~kg} / \mathrm{d}$ for the control and high-WSC grasses, respectively, which is consistent with the simulation results in Tables 6 and 7 .

Evaluation of the apparently inconsistent effects of high-WSC grasses on milk yield in the literature, taken in context of the simulations performed here, shows that the relationship is sensitive to DM ( $\mathrm{g} / \mathrm{kg}$ of $\mathrm{DM})$ composition of the plant, whether WSC is increasing at the expense of CP (e.g., such as would be achieved by altering $\mathrm{N}$ fertilization levels), NDF (e.g., due to specific cultivar breeding), or a combination of the 2 (e.g., due to a dilution effect, see Rasmussen et al., 2009). Simulation results suggest that only when WSC increases at the expense of NDF are large increases in milk yield seen, whereas smaller increases will be seen when both NDF and CP decrease at the expense of an increase in WSC, and that milk yield may decrease slightly when CP decreases as WSC increases.

Level of DM Exchange. It is evident from the results simulated here, as well as from data reported in the literature, that the level of DM exchanged between WSC, CP, and NDF are of vital importance to the magnitude of the results obtained. In the simulations and in the literature, marginal effects are obtained for an increase of WSC at a level of approximately $20 \mathrm{~g} / \mathrm{kg}$ of DM or less, whereas larger effects are seen at higher exchange levels. The present study may be used as a rough guide for the level of response to be expected for increases in WSC content in grass, and for targeting plant WSC levels and compositions.

High Versus Low Basal N Content of Grass. The proposed mode of action for high-WSC grasses is that the increased supply of energy should enhance the capture of $\mathrm{N}$ in the rumen, thereby increasing the supply of protein to the ruminant. The most promising results in terms of milk yield were observed by Miller et al. (2001a), who also had substantially lower DM digestibility values compared with some of the other studies mentioned (e.g., Tas et al., 2005, 2006a). Edwards et al. (2007) suggested that greater responses in animal performance might be expected in systems where the ruminant is protein limited, rather than in those where the ruminant is energy limited. Protein could be limited due to low digestibility values or low $\mathrm{N}$ content in grass. Because of this, 2 scenarios were considered in this study, representing high (simulations 11-20 and 31-40) and low (simulations 1-10 and 2130) $\mathrm{N}$ fertilization levels of simulated grasses. Results 
are compared for the no-grain (simulations 1-10 and 21-30) scenarios as they represent the lowest CP diets.

In terms of milk yield, across all simulations, the average increase in milk yield for the low $\mathrm{N}$ grasses was $1.7 \%(0.35 \mathrm{~kg} / \mathrm{d})$ compared with the basal diet. The average increase for the high $\mathrm{N}$ grasses was $1.5 \%$ (0.34 $\mathrm{kg} / \mathrm{d}$ ) compared with the basal diet. These values are low because they are averages of scenarios where predicted milk yield increased as well as scenarios where it decreased. Therefore, a very slight advantage is seen in the low $\mathrm{N}$ data in terms of milk yield, which would probably not be significantly different with observational data.

In terms of $\mathrm{N}$ excretion, average urine $\mathrm{N}$ (\% of $\mathrm{N}$ intake) decreased by $15.9 \%$ for the low $\mathrm{N}$ simulations as a result of WSC increase, and by $8.6 \%$ for the high $\mathrm{N}$ simulations. Similarly, the N utilization ratio increased by $38.7 \%$ for the low $\mathrm{N}$ simulations and by $32.6 \%$ for the high $\mathrm{N}$ simulations, and total $\mathrm{N}$ excretion (\% of $\mathrm{N}$ intake) decreased by $19.3 \%$ for the low $\mathrm{N}$ simulations compared with $14.6 \%$ for the high $\mathrm{N}$ simulations. These results seem to confirm the statement of Edwards et al. (2007) that a greater effect will be seen in terms of $\mathrm{N}$ excretion when $\mathrm{N}$ intake or diet digestibility is low.

Grain Feeding. As some studies in the literature feed supplemental grain and others do not, simulations were performed here with and without $2 \mathrm{~kg} / \mathrm{d}$ of grain feeding (Tables 4 and 6 vs. Tables 5 and 7 ). Similar to altering the $\mathrm{N}$ fertilization level of grass, adding grain to the diet in the simulations increased $\mathrm{N}$ and energy intake. Averaged across the grain-fed and across the no-grain-fed simulations, milk yield increased $1.59 \%$ without grain feeding compared with $1.09 \%$ with grain feeding with increased WSC content of grass. In terms of $\mathrm{N}$ excretion, urine $\mathrm{N}$ (\% of $\mathrm{N}$ intake) decreased by $12.3 \%$ without grain feeding compared with $11.2 \%$ with grain feeding, the $\mathrm{N}$ utilization ratio decreased by $35.7 \%$ without grain feeding compared with $29.2 \%$ with grain feeding, and total $\mathrm{N}$ excretion (\% of $\mathrm{N}$ intake) decreased by $16.9 \%$ without grain feeding compared with $15.3 \%$ with grain feeding. Again, results show a tendency for higher levels of improvement on lower quality diets, and this may be another source of variation for the data in the literature. This variation may also depend on the composition of the grain fraction and level of grain intake.

WSC:CP Ratio. Edwards et al. (2007) suggested that the lack of response in some published data to high WSC content of grass may be that despite large differences in WSC content, only small differences occurred in the WSC:CP ratio of the high-WSC and control diets. Table 2 reports the WSC:CP ratios of all of the simulations performed here, which range from 0.48 to 2.37. Plotting, across all simulations, the WSC:CP

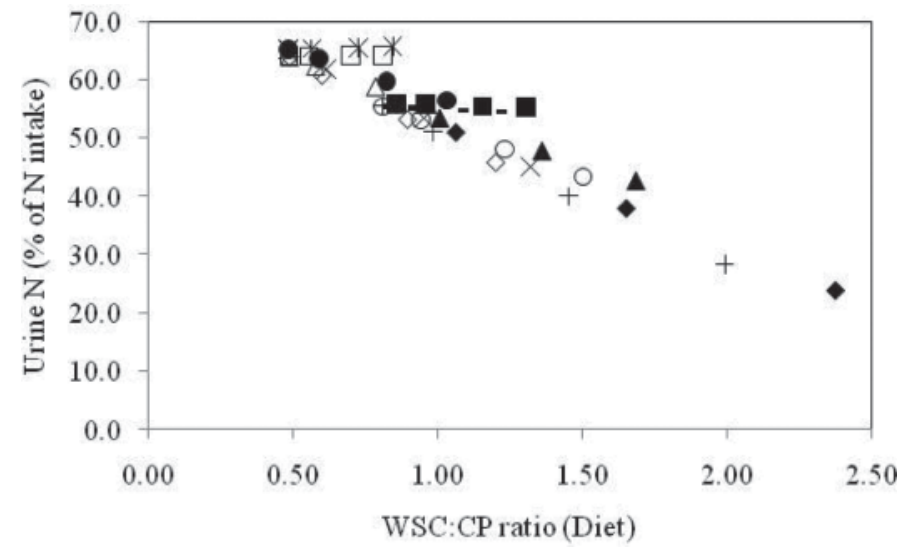

Figure 5. Simulated urine N (\% of N intake) versus the diet watersoluble carbohydrate (WSC):CP ratio, for simulations 1-4 (•), 5-7

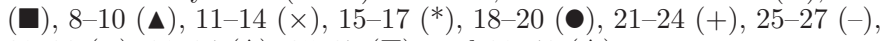
28-30 $(\bigcirc), 31-34(\diamond), 35-37(\square)$, and 38-40 $(\Delta)$.

ratio of the diet versus urine $\mathrm{N}$ (\% of $\mathrm{N}$ intake) showed a strong negative relationship, with $\mathrm{R}^{2}=0.90$ (Figure 5). Indeed, the hypothesis behind the use of high-WSC grasses is that high WSC intake may correct an imbalance in the supply of energy and protein to the rumen, and thus the balance of WSC and CP is central to the hypothesized mode of action. Edwards et al. (2007) also stated that minimal effect on urine $\mathrm{N}$ (\% N intake) was observed below a WSC:CP ratio of 0.7 , but that at values greater than 0.7 more marked reductions in urine $\mathrm{N}$ were observed. When the results from simulations performed here are plotted according to their WSC scenario (Table 2), it is evident that those simulations in which WSC increases at the expense of NDF (simulations 5-7, 15-17, 25-27, and 35-37) have lower initial WSC:CP ratio, and that no change in urine $\mathrm{N}$ is obtained. However, other simulations have similar initial WSC:CP ratios, yet a decrease in urine $\mathrm{N}$ is observed. Simulations here show that not all WSC:CP ratios less than 0.7 have no effect on, for example, urine $\mathrm{N}$, and we therefore suggest that not only the WSC and CP fractions are important in determining the magnitude of response to high WSC grasses, but also NDF.

\section{CONCLUSIONS}

According to the present modeling exercise, $\mathrm{N}$ excretion is expected to decrease and $\mathrm{N}$ utilization ratio to increase when high-WSC grasses are fed. However, the magnitude of effects depends on (1) whether WSC increases at the expense of $\mathrm{CP}, \mathrm{NDF}$, or a combination of the two; (2) the level of $\mathrm{g} / \mathrm{kg}$ of DM exchange; and (3) the level of basal $\mathrm{N}$ fertilization and whether the animals are supplemented with grain. The largest increase in N efficiency is expected when WSC increases 
at the expense of $\mathrm{CP}$, followed by a combination of $\mathrm{CP}$ and NDF, followed by NDF. When WSC increases at the expense of $\mathrm{CP}$, milk yield is expected to decline slightly (up to $-1.5 \mathrm{~kg} / \mathrm{d}$ ), but is expected to increase when WSC increases at the expense of a combination of $\mathrm{CP}$ and NDF (up to $+0.6 \mathrm{~kg} / \mathrm{d}$ ), and more so when WSC increases at the expense of NDF alone (up to $+2.4 \mathrm{~kg} / \mathrm{d}$ ). In general, simulated effects were amplified under conditions of a lower plane of nutrition (e.g., low grass $\mathrm{N}$ fertilization levels or the absence of grain feeding). These results are generally in line with observational data, and explain at least some of the variation observed. High-WSC grasses may indeed increase the efficiency of $\mathrm{N}$ utilization and milk yield, but results will depend on the composition of the grass and the diet under consideration.

\section{ACKNOWLEDGMENTS}

Funding for this project was provided by the Canada Research Chairs Program and the Natural Sciences and Engineering Research Council's Strategic Grants Program. The Sesnon Endowed Chair Program (UC Davis) is also acknowledged. J. L. Ellis received a Wageningen Institute of Animal Sciences (WIAS) research fellowship in 2008, as well as funding from the Animal Sciences Group (Wageningen UR, Lelystad, the Netherlands). Authors Parsons, Rasmussen, and Edwards were partly funded by FRST (NZ) "Novel Traits" programme (C10X0903) and FRST/DairyNZ programme P21.

\section{REFERENCES}

Abrahamse, P. A., S. Tamminga, and J. Dijkstra. 2009. Effect of daily movement of dairy cattle to fresh grass in morning or afternoon on intake, grazing behaviour, rumen fermentation and milk production. J. Dairy Sci. 71:1178-1188.

AFRC. 1993. Energy and Protein Requirements of Ruminants. CAB International, Wallingford, UK.

Bannink, A., J. France, S. López, W. J. J. Gerrits, E. Kebreab, S. Tamminga, and J. Dijkstra. 2008. Modelling the implications of feeding strategy on rumen fermentation and functioning of the rumen wall. Anim. Feed Sci. Technol. 143:3-26.

Bernard, J. K. 1997. Milk production and composition responses to the source of protein supplements in diets containing wheat middlings. J. Dairy Sci. 80:938-942.

Bibby, J., and T. Toutenburg. 1977. Prediction and Improved Estimation in Linear Models. John Wiley \& Sons, Chichester, UK.

Castillo, A. R., E. Kebreab, D. E. Beever, and J. France. 2000. A review of efficiency of nitrogen utilisation in dairy cows and its relationship with the environmental pollution. J. Anim. Feed Sci. 9:1-32.

Centraal Veevoederbureau (CVB). 2007. CVB Table Ruminants 2007, series nr 32. CVB, The Hague, the Netherlands.

Cosgrove, G. P., J. L. Burke, A. F. Death, M. J. Hickey, D. Pacheco, K. Fraser, and G. A. Lane. 2007. Ryegrass with increased water soluble carbohydrate: Evaluating the potential for grazing dairy cows in New Zealand. Proc. N.Z. Grassl. Assoc. 69:179-185.
Dijkstra, J., J. France, A. G. Assis, H. D. St. C. Neal, O. F. Campos, and L. J. M. Aroeira. 1996. Simulation of digestion in cattle fed sugarcane: Prediction of nutrient supply for milk production with locally available supplements. J. Agric. Sci. Camb. 127:247-260.

Dijkstra, J., E. Kebreab, A. Bannink, L. A. Crompton, S. Lopez, P. A. Abrahamse, P. Chilibroste, J. A. N. Mills, and J. France. 2008. Comparison of energy evaluation systems and a mechanistic model for milk production by dairy cattle offered fresh grass-based diets. Anim. Feed Sci. Technol. 143:203-219.

Dijkstra, J., D. St. C. Neal, D. E. Beever, and J. France. 1992. Simulation of nutrient digestion, absorption and outflow in the rumen: Model description. J. Nutr. 122:2239-2256.

Edwards, G. R., A. J. Parsons, and S. Rasmussen. 2007. High sugar ryegrasses for dairy systems. Pages 307-334 in Meeting the Challenges for Pasture-Based Dairying. Proceedings of the Australasian Dairy Science Symposium. D. F. Chapman, D. A. Clark, K. L. MacMillan and D. P. Nation, ed. University of Melbourne, National Dairy Alliance, Melbourne, Australia.

Kebreab, E., J. France, J. A. Mills, R. Allison, and J. Dijkstra. 2002. A dynamic model of $\mathrm{N}$ metabolism in the lactating dairy cow and an assessment of impact of $\mathrm{N}$ excretion on the environment. J. Anim. Sci. 80:248-259.

Lee, M. R. F., L. J. Harris, J. M. Moorby, M. O. Humphreys, M. K. Theodorou, J. C. MacRae, and N. D. Scollan. 2002. Rumen metabolism and nitrogen flow to the small intestine in steers offered Lolium perenne containing different levels of water-soluble carbohydrate. Anim. Sci. 74:587-596.

Lin, L. I. K. 1989. A concordance correlation coefficient to evaluate reproducibility. Biometrics 45:255-268.

Miller, L. A., D. H. Baker, M. K. Theodorou, J. C. MacRae, M. O. Humphreys, N. D. Scollan, and J. M. Moorby. 2001b. Efficiency of nitrogen use in dairy cows grazing ryegrass with different water soluble carbohydrate concentrations. Pages 377-378 in Grassland Ecosystems: An Outlook into the 21st Century. Proc. 19th Int. Grassl. Congr. J. A. Gomide, W. R. S. Mattos, and S. Carneiro da Silva, ed. Sao Paulo, Brazil.

Miller, L. A., J. M. Moorby, D. R. Davies, M. O. Humphreys, N. D. Scollan, J. C. MacRae, and M. K. Theodorou. 2001a. Increased concentration of water-soluble carbohydrate in perennial ryegrass (Lolium perenne L.): Milk production from late-lactation dairy cows. Grass Forage Sci. 56:383-394.

Miller, L. A., M. K. Theodorou, J. C. MacRae, R. T. Evans, M. O. Humphreys, N. D. Scollan, and J. M. Moorby. 2000. Efficiency of nitrogen use by dairy cows offered perennial ryegrass with high water soluble carbohydrate concentrations. Pages 37-38 in Proc. 6th Res. Conf. Br. Grassl. Soc., Aberdeen, UK.

Mills, J. A. N., J. Dijkstra, A. Bannink, S. B. Cammell, E. Kebreab, and J. France. 2001. A mechanistic model of whole-tract digestion and methanogenesis in the lactating dairy cow: Model development, evaluation and application. J. Anim. Sci. 79:1584-1597.

Moorby, J. M., R. T. Evans, N. D. Scollan, J. C. MacRae, and M. K. Theodorou. 2006. Increased concentration of water-soluble carbohydrate in perennial ryegrass (Lolium perenne L.). Evaluation in dairy cows in early lactation. Grass Forage Sci. 61:52-59.

Murphy, M. R., R. L. Baldwin, and L. J. Koong. 1982. Estimation of stoichiometric parameters for rumen fermentation of roughage and concentrate diets. J. Anim. Sci. 55:411-421.

Rasmussen, S., A. J. Parsons, H. Xue, and J. A. Newman. 2009. High sugar grasses - Harnessing the benefits of new cultivars through growth management. Proc. N.Z. Grassl. Assoc. 71:167-175.

Reijs, J. W. 2007. Improving slurry by diet adjustments. A novelty to reduce $\mathrm{N}$ losses from grassland based dairy farms. $\mathrm{PhD}$ Thesis. Wageningen University, Wageningen, the Netherlands.

Sauvant, D., J.-M. Perez, and G. Tran, ed. 2004. Tables of composition and nutritional value of feed materials. Wageningen Academic Publishers, Wageningen, the Netherlands, and Institut National de la Recherche Agronomique, Paris, France.

Seo, S., L. O. Tedeschi, C. Lanzas, C. G. Schwab, and D. G. Fox. 2006 Development and evaluation of empirical equations to predict feed passage rate in cattle. Anim. Feed Sci. Technol. 128:67-83. 
Tas, B. M., H. Z. Taweel, H. J. Smit, A. Elgersma, J. Dijkstra, and S. Tamminga. 2005. Effects of perennial ryegrass cultivars on intake, digestibility and milk yield in dairy cows. J. Dairy Sci. 88:3240-3248.

Tas, B. M., H. Z. Taweel, H. J. Smit, A. Elgersma, J. Dijkstra, and S. Tamminga. 2006a. Utilisation of $\mathrm{N}$ in perennial ryegrass cultivars by stall-fed lactating dairy cows. Livest. Sci. 100:159-168.

Tas, B. M., H. Z. Taweel, H. J. Smit, A. Elgersma, J. Dijkstra, and S. Tamminga. 2006b. Effects of perennial ryegrass cultivars on milk yield and nitrogen utilisation in grazing dairy cows. J. Dairy Sci. 89:3494-3500.

Tavendale, M. H., D. Pacheco, G. A. Lane, K. Fraser, A. F. Death, J. L. Burke, M. J. Hickey, and G. P. Cosgrove. 2006. The effects of ryegrass varieties differing in soluble sugar content on the rumen fermentation of amino acids and consequences for milk flavor chemistry. Proc. N.Z. Grassl. Assoc. 68:267-273.

Taweel, H. Z., B. M. Tas, H. J. Smit, A. Elgersma, J. Dijkstra, and S. Tamminga. 2005a. Effects of feeding perennial ryegrass with an elevated concentration of water-soluble carbohydrate on intake, rumen function and performance of dairy cows. Anim. Feed Sci. Technol. 121:243-256.
Taweel, H. Z., B. M. Tas, H. J. Smit, A. Elgersma, J. Dijkstra, and S. Tamminga. 2005b. Improving the quality of perennial ryegrass (Lolium perenne L.) for dairy cows by selecting for fast clearing and/or degradable neutral detergent fiber. Livest. Prod. Sci 96:239-248.

Taweel, H. Z., B. M. Tas, H. J. Smit, A. Elgersma, J. Dijkstra, and S. Tamminga. 2006. Grazing behaviour, intake, rumen function and milk production of dairy cows offered Lolium perenne containing different levels of water-soluble carbohydrates. Livest. Sci. 102:33-41.

Valk, H. 2002. Nitrogen and phosphorus supply of dairy cows. PhD Thesis. Wageningen University, Wageningen, the Netherlands.

Valk, H., I. E. Kappers, and S. Tamminga. 1996. In sacco degradation characteristics of organic matter, neutral detergent fibre and crude protein of fresh grass fertilized with different amounts of nitrogen. Anim. Feed Sci. Technol. 63:63-87.

Valk, H., I. E. Leusink-Kappers, and A. M. van Vuuren. 2000. Effect of reducing nitrogen fertilizer on grassland on grass intake, digestibility and milk production of dairy cows. Livest. Prod. Sci. 63:27-38. 